\title{
Authenticity and creativity: The development of pencak silat in Sumedang
}

\section{Otentisitas dan kreasi: Perkembangan pencak silat di Sumedang}

\author{
Semiarto A. Purwanto ${ }^{1}$, Andi R. Saputra ${ }^{2}$ \\ ${ }^{1}$ Department of Anthropology, University of Indonesia, Indonesia. E-mail: semiarto.aji09@ui.ac.id \\ 2 Research and Development Division, Kampung Silat Jampang, Bogor, Indonesia. \\ E-mail: andi.rahmanasaputra@gmail.com
}

\begin{tabular}{|c|c|}
\hline ARTICLE INFO & ABSTRACT \\
\hline $\begin{array}{l}\text { How to cite: } \\
\text { Purwanto, S.A., Saputra, } \\
\text { A.R. (2020). Otentitas dan } \\
\text { kreasi: Perkembangan } \\
\text { pencak silat di Sumedang. } \\
\text { ETNOSIA: Jurnal } \\
\text { Etnografi Indonesia. 5(1): } \\
15 \text { - 32. } \\
\text { DOI: } \\
\text { 10.31947/etnosia.v5i1.9641 }\end{array}$ & $\begin{array}{l}\text { Many studies of silat have documented the jurus (moves) or aliran } \\
\text { (streams) in silat, especially those based on tradition. Even so, there } \\
\text { are still many things about this martial arts tradition that have not } \\
\text { been deeply touched, for instance, how it can be developed without } \\
\text { losing the authenticity of the tradition. We exercise it as a problem of } \\
\text { how tradition and change should be defined, how authenticity is } \\
\text { placed in a dynamic context, and how silat practitioners continue } \\
\text { their creativity. Within an anthropological perspective, we put } \\
\text { forward the case of the Perguruan Silat Garuda Putih in Sumedang } \\
\text { to study how the individual ideas, learning process, and creations; } \\
\text { and authenticity, structure, and power are tied together. The } \\
\text { Sumedang silat tradition which originated from various aliran has } \\
\text { been structured as a unique gaya (style) of fighting. The role of } \\
\text { perguruan (silat training center), systematically keeps a beginner in } \\
\text { silat to learn standard silat. At the end of learning, however, we } \\
\text { believe that the process of creating moves and ibing (opening } \\
\text { movements) shows a high dynamic amidst creativity, aligning } \\
\text { movements with standards, maintaining authenticity, but at the } \\
\text { same time also marking the individual characteristics of students. }\end{array}$ \\
\hline
\end{tabular}

\section{Pendahuluan}

Pada hari Kamis, tanggal 12 Desember 2019, di Bogota, Kolumbia, UNESCO menetapkan pencak silat sebagai warisan budaya tak benda. Melalui melalui sidang ke 14 Intergovernmental Committee for the Safeguarding of the Intangible Cultural Heritage, Indonesia dan Malaysia dinyatakan sebagai pewaris pencak silat. Persebaran tradisi silat memang luas, tidak hanya di Indonesia tetapi juga di Malaysia dan Thailand (Paetzold \& Mason 2016; Draeger 1972). Tidak sekedar menjadi bagian dari kekayaan etnik, pencak silat menjelma menjadi olahraga prestasi dan seni tarung yang memiliki 
nilai jual dalam perfilman di Indonesia. Pendeknya, perkembangan pencak silat di tanah air telah demikian pesat. Artikel ini akan membahas bagaimana kita memandang perkembangan pencak silat dari kacamata antropologi, khususnya dalam perspektif otentisitas dan struktur yang membatasi proses kreativitas budaya.

Dari waktu ke waktu, perkembangan perguruan pencak silat berkembang pesat di Indonesia. Salah satu yang tertua adalah Perguruan Setia Hati Terate yang mulai dirintis oleh seorang priyayi Jawa bernama Ki Ageng Soerodiwirjo di Madiun, Jawa Timur tahun 1903 (Utomo 2017). Alasan berdirinya perguruan ini adalah untuk memperkuat rasa persaudaraan dan kepribadian Jawa (Indonesia) di masa kolonial ${ }^{1}$. Peran para priyayi, khususnya para bangsawan, nampaknya cukup besar pada awal berkembangnya perguruan silat di masa kolonial. Walaupun baru resmi berdiri tahun 1963, Perguruan Pencak Silat Beladiri Tangan Kosong Merpati Putih, misalnya, telah dirintis oleh para bangsawan Kerajaaan Mataram di Kartasura, Jawa Tengah². Peran utama perguruan ini adalah untuk membentuk watak dan kepribadian Indonesia yang luhur (Khunaefi 2015). Perguruan lainnya, misalnya Tapak Suci, berdiri dalam naungan salah satu organisasi agama tertua di Indonesia, yaitu Muhammadiyah³. Tapak Suci berdiri tahun 1963 dan berkembang bersamaan dengan perkembangan gerakan pendidikan Muhammadiyah (Rudianto 2011).

Walaupun banyak perguruan silat mengembangkan tradisi etnik Indonesia, tak dapat dipungkiri bahwa pengaruh India, melalui agama Hindu dan Budha, Islam, dan Cina (Draeger 1972 Kartomi 2011; Wilson 2002), amat besar dalam perkembangan silat. Salah satu perguruan silat terkemuka seperti Perguruan Bangau Putih, misalnya, didirikan oleh keluarga Cina Hokkien yang tinggal di Bogor dan berkembang di Jakarta. Selang dua dasawarsa berikut, barulah mulai masuk warna pribumi di perguruan tersebut (Samudra 2006). Melihat silat memang harus lebih terbuka mengingat banyaknya pengaruh budaya luar Indonesia yang ikut mewarnainya (Draeger 1972; Paetzold \& Mason 2016). Sekalipun demikian, jelas terlihat warna dan corak khas berupa tradisi etnik atau tradisi lokal yang mewarnai pencak silat di Indonesia.

Sejak tahun 1948, persilatan di Indonesia mulai dikembangkan secara lebih sistematis melalui pendirian Ikatan Pencak Silat Indonesia (IPSI) di Surakarta, Jawa Tengah. Salah satu kegiatan utama yang dilakukan IPSI adalah melakukan standarisasi metode belajar silat yang dilakukan perguruan pencak silat anggotanya (de Grave 2016; Pratama \& Trilaksana 2018). Para pelatih pencak dari berbagai aliran melakukan standarisasi pengajaran pencak silat dengan membuat kurikulum dan melembagakan perguruan mereka dengan mendaftarkannya ke IPSI (Wilson 2002:126). Standarisasi tersebut bukan hanya terletak pada pola pengajaran tetapi juga pada teknik gerakan. Salah satu standar gerakan yang tercipta adalah Teknik Gerak Rangkaian (TGR) yang dibuat oleh IPSI (Kriswanto 2012). TGR merupakan rangkaian gerakan yang dibuat dengan menggabungkan berbagai gerakan dari beberapa perguruan pencak silat yang

\footnotetext{
${ }^{1}$ Pernyataan ini dapat dilihat pada https://www.shterate.com/category/sejarah-psht/

${ }^{2}$ Lihat http://www.ppsbetakomerpatiputih.com/

${ }^{3}$ Lihat https://pimpinanpusattapaksuci.org/.
} 
ada di Indonesia dengan standar ini, silat lalu dapat dipertandingkan di tingkat nasional dan internasional (Nugroho 2005).

Ketika standar sudah tercapai, dan perkembangan silat berjalan dalam koridor tersebut, kekhasan aliran yang menjadikan setiap pencak silat berbeda satu sama lain, perlahan menjadi semakin memudar. Beragam aliran pencak silat, tampaknya, perlahan-lahan kehilangan karakter utamanya. Kami akan mengkaji dan mengkritisi proses standarisasi silat di satu sisi, dengan kekhasan atau otentisitas pencak silat di sisi lain. Pertanyaan yang kami ajukan adalah tentang bagaimana kita memahami perkembangan pencak silat saat ini dan di mana kita meletakkan kekhasan gerak yang menjadi ciri suatu perguruan silat dalam perspektif gerakan silat yang semakin terstandarisasi.

\section{Struktur, Standarisasi, Otentisitas, dan Kreasi}

Dalam perspektif antropologi, setiap tradisi memiliki kemampuan untuk memproduksi dan mereproduksi diri (Bourdieu 1977, 1983; Willis 1981), sementara setiap komunitas memiliki kreativitas tertentu untuk memodifikasi tradisi sehingga dapat terus bertahan dan menjadi ciri yang khas (Broner 2011; Theodossopoulos 2013). Dalam perspektif ini, kami meneliti kasus silat di Perguruan Garuda Putih Setia Kawan Putra di Sumedang, Jawa Barat, dan mendapatkan gambaran bagaimana kreativitas para pesilat tetap merupakan suatu hal yang dinilai tinggi di antara serangkaian gerak standar yang harus dikuasai ketika berlatih.

Dalam teori-teori yang dikembangkan Bourdieu, individu dan masyarakat diletakkan secara relational; keduanya berhubungan sebagai satu realitas sosial (Swartz 2012). Individu sebagai pelaku (actor) selalu tak lepas dari pengaruh masyarakat dalam bentuk struktur yang telah disepakati (structured structures). Berbagai pengalaman individual distrukturkan sebagai suatu pengetahuan kolektif dan kemudian menjadi acuan bagi individu agar dapat diterima dalam masyarakat. Bourdieu (1990:53) menjelaskan teorinya tentang habitus, sebagai

"a system of durable, transposable dispositions, structured structures predisposed to function as structuring structures, that is, as principles which generate and organize practices and representations that can be objectively adapted to their outcomes without presupposing a conscious aiming at ends or an express mastery of the operations necessary in order to attain them"

Dalam rumusan yang lain, habitus juga merupakan system of durable, transposable dispositions which functions as the generative basis of structured, objectively unified practiced (Swartz 2012:100). Dengan perspektif ini, seorang yang belajar silat sebenarnya tengah menstrukturkan berbagai pengetehuan dan pengalamannya memahami gerak dan jurus, baik dalam konteks seni maupun pertarungan. Kami melihat bahwa kegiatan belajar silat adalah suatu ranah yang membuat berbagai pengetahuan dan pengalaman tentang gerak dan jurus tadi menjadi lebih berpola. Semakin dia berlatih, semakin dia memahami pola dan mulai memilah mana gerak yang baik dan mana yang buruk. Gerakan apa yang paling efektif dan mana yang hanya membuang tenaga. Semakin dia mendalami silat, ketika berhadapan dengan lawan, maka dia akan paham jurus atau gerakan yang dimainkan lawan. Bahkan dia juga akan sadar apakah lawannya 
seorang awam yang tak terlatih, atau bisa bermain silat, atau seorang yang amat mahir bersilat. Ketika setiap gerakan sudah menyatu dalam diri seorang pesilat, atau menjadi habitus bagi seorang individu, maka gerakan-gerakan tersebut dapat muncul begitu saja tanpa harus dipikirkan terlebih dahulu. Kuda-kuda, bukaan, dan jurus yang diperagakan akan keluar secara natural. Bahkan tidak jarang refleks dari seorang yang belajar silat akan menampakkan suatu jurus tertentu.

Ketika suatu jurus silat dikembangkan, seorang pesilat mungkin mengamati fenomena di alam atau binatang di sekelilingnya (Kartomi 2011, Wilson 2002:28). Dia mulai mencoba menirukan gerak yang kemudian dimantapkan atau distrukturkan sebagai jurus-jurus silat. Dari awal, Bourdieu (1977) sudah mengingatkan bahwa selain ada proses internal dalam diri individu, selalu saja ada sebuah kekuatan dominan, yaitu ranah kekuasaan, yang melebihi individu. Oleh karena itu, seringkali seorang pesilat tidak selalu bebas mengembangkan jurus-jurusnya. Ada pesilat lain, mungkin lawannya yang akan mematahkan jurus-jurusnya; atau mungkin gurunya, yang akan memberitahu gerakan mana yang lebih tepat. Amat kental dalam hal ini bagaimana seorang individu harus melakukan disposisi dalam mengembangkan jurus silat. Di sisi lain, terlihat juga adanya kekuatan yang lebih dominan dalam memberikan warna pada corak jurus yang akan dikembangkan.

Menarik untuk melihat bagaimana peran guru dan perguruan silat yang merupakan basis pendidikan dari silat. Dalam perspektif ini, lembaga pendidikan berupa sekolah atau perguruan selalu saja merupakan sebuah institusi dominan yang memberikan standar segala hal yang dipelajari dan harus dicapai oleh murid. Dominasi ini semakin nyata ketika perguruan-perguruan silat bersatu di dalam IPSI. Sebagai lembaga nasional, IPSI nampak begitu berkuasa mengarahkan mana saja perguruan yang baik dan benar, bahkan bisa menegur perguruan yang melanggar. IPSI juga menentukan gerak dasar yang diterima oleh semua anggota; demikian pula dengan aturan permainan silat. Semua pesilat, terutama yang berguru pada lembaga di bawah IPSI, harus mengikuti aturan tersebut. Ketimpangan kuasa ini dalam pandangan Bourdieu seperti senantiasa direproduksi.

Di sisi lain, suatu perilaku selalu berada dalam ranah budaya (cultural fields) yang berkembang melalui proses kreasi (Willis 1981). Oleh karena itu, walaupun ada jurus baku, setiap individu selalu saja memiliki kecenderungan menampilkan kekhasan tertentu. Semakin seseorang ingin menampilkan kekhasannya, maka semakin tinggi sebenarnya tarikan dari sebuah struktur untuk menyelaraskan ke dalam gerak baku. Apabila seorang individu berhasil keluar, dan memiliki warna baru yang berbeda dengan gerakan yang baku, maka gerak tersebut menjadi milik otentik orang tersebut.

Dalam studinya mengenai pemukul kendang dalam orkes yang mengiringi latihan silat di Jawa Barat, Mason (2016) dan Paetzold (2016) bercerita tentang seorang pemain kendang buta. Menabuh irama kendang untuk mengiringi latihan silat tentu harus mengikuti irama tertentu. Seorang penabuh kendang harus memahami tempo, kekuatan, dan momentum saat dia harus menepuk kendangnya. Tidak heran bila orang seorang pesilat dapat bergerak mengikuti irama kendang, siapapun penabuhnya karena irama kendang yang amat terstruktur. Menariknya, Paetzold (2011:81) mengatakan bahwa sang pemain kendang buta mampu mengenali siapa orang yang 
menabuh kendang hanya dengan mendengarkan improvisasi dari pemain kendang; sesuatu yang otentik dengan pemain tersebut. Setiap tradisi dalam bahasan Linnekin (1991) selalu menyediakan ruang bagi individu untuk melakukan invensi atau improvisasi, sehingga walaupun perilaku mereka serupa, tapi tetap terlihat otentisitasnya.

\section{Metode}

Penelitian ini dilakukan di Kabupaten Sumedang dalam rentang enam bulan dari Juli sampai Desember 2019. Purwanto melakukan kunjungan lapangan tiga kali selama kurun waktu 2019, masing-masing selama 3-5 hari. Kemudian, Saputra melakukan pengamatan lebih dalam selama satu bulan di awal Oktober sampai pertengahan November 2019. Penelitian dilakukan menggunakan metode etnografi dengan cara tinggal bersama dengan informan, melalukan wawancara mendalam dan juga pengamatan terlibat.

Fokus pencarian data lapangan adalah untuk menjawab pertanyaan mengenai otentisitas dalam pencak silat yang ada di Sumedang. Sebagai daerah yang pernah menjadi lokasi berdirinya Kerajaan Sumedang Larang, Sumedang memiliki karakteristik pencak silat yang unik dibandingkan dengan tempat lainnya. Kekhasan ini menjadi salah satu hal yang kami telusuri dan akan diskusikan dalam tulisan ini.

Sebanyak enam informan dari keluarga perguruan Garuda Putih kami wawancara untuk mendapatkan data mengenai riwayat perguruan, kekhasan, dan dinamika perkembangannya. Mereka adalah pendiri dan guru besar perguruan, empat pesilat simpay wulung, dan satu persilta muda yang sudah mencapai tahap pelatih. Sebagai pembanding, kami mewawancarai tiga tokoh silat di luar Garuda Putih yang mewakili aliran silat tua Dharma Bakti, silat Cimande dan Silat Cikalong di Sumedang. Kami menambahkan empat informan untuk memperdalam konteks tradisi dan kehidupan sehari-hari masyarakat Sumedang.

\section{Hasil penelitian dan pembahasan}

\section{- Perguruan garuda putih dan pencak silat sumedang}

Salah satu perguruan yang diklaim mengembangkan dan mewarisi pencak silat asli Sumedang adalah Garuda Putih Setia Kawan. Secara singkat, nama perguruan itu sering disebut sebagai Garuda Putih. Sebelumnya bernama Tengkorak Putih, perguruan silat ini didirikan oleh seorang purnawirawan Tentara Nasional Indonesia bernama Letnan Syarif tahun 1960. Tengkorak Putih adalah nama batalyon yang menjadi andalan TNI untuk menumpas geromoblan separatis dasawarsa 1950-1960. Karena dianggap terlalu menakutkan dan kurang menarik minat generasi muda untuk bergabung, nama Tengkorak Putih diubah menjadi Garuda Putih pada tahun 1990an. Walaupun demikian, nama Tengkorak Putih masih sering digunakan dalam pembicaraan internal di perguruan. Sayangnya, tetap tidak banyak orang tertarik berlatih silat, sehingga Abah Kusmana atau Abah Aus, seorang murid dari Letnan Syarif, sebagai pewaris dari perguruan sempat meminimalkan aktivitas perguruan. Tahun 2009, setelah didorong murid-muridnya, ia mendirikan padepokan atau paguron 
pencak silat di Desa Citimun dengan nama Garuda Putih Setia Kawan Putra Tengkorak Putih disingkat Garuda Putih.

Pencak silat Sumedang merupakan hasil pencampuran dari beragam gaya atau aliran yang ada di Jawa Barat. Di provinsi ini, menurut Wilson (2002:38) terdapat tiga aliran besar yang berkembang sejak 200 tahun yang lalu yaitu Cimande, Cikalong, dan Syahbandar, ditambah dua aliran kecil Kari dan Madi yang masih berhubungan dengan ketiga aliran besar itu. Garuda Putih, dalam hal ini, memiliki teknik jurus yang berasal dari percampuran antara silat Cimande, Cikalong, Syahbandar, dan silat Madi. Dalam wawancara dengan kami, Abah Aus menyampaikan bahwa Garuda Putih merupakan perguruan pencak silat yang mengombinasikan teknik gerak dari beberapa aliran pencak silat tersebut. Penggabungan berbagai gerak jurus dari berbagai aliran pencak silat oleh masing-masing perguruan telah lama dilakukan hingga kini seolah tidak ada lagi gerak jurus yang khas. Abah Aus mengatakan bahwa pencak silat yang ada di Sumedang hampir semuanya memiliki gerak jurus yang serupa hanya berbeda nama dan sedikit memiliki perbedaan dalam sikap berdiri dan gerak langkah.

"ada orang Cirebon dianya mau tahu jurus Kesumedangan. Semuanya padepokan yang ada di Sumedang dipanggil ke Gedung Negara. Ketika diperhatikan, gerakannya mirip semua. Kesimpulannya gerakannya berhubung sudah lama (bercampur), satu Sumedang juga hampir sama gerakannya."

"Jadi memang kalau jurusnya susah sih cari yang asli Sumedang juga. Waktu di Gedung Negara teh. Nah ada yang jawab katanya "kalau mau lihat jurus asli Sumedang, lihat aja di Cadas Pangeran tuh. Pangeran itu sama Belanda itu. Asli sumedang itu yang kiri nerima tangan orang yang kanan pegang keris, pegang pusaka. Nah itu jurus asli Sumedang itu kalau jabat tangan itu. Itu aslinya jurus Sumedang itu. Malah dulu kan di Gedung Negara dijelaskan gitu. Cuman itu yang asli itu (tertawa). Yang satu megang tangan yang satu megang pusaka. Nah jurusnya itu".

Meskipun pencak silat yang ada di Sumedang merupakan hasil percampuran gerak jurus dari beragam aliran yang ada di Jawa Barat, tetapi ada suatu jurus yang dianggap sebagai jurus tua atau buhun. Jurus silat buhun tidak dianggap sebagai tata gerak jurus asli Sumedang tetapi merupakan gerak jurus tua yang dipraktikkan sejak masa kolonial Belanda. Saat ini gerak jurus silat buhun diyakini masih dipraktikkan oleh para sesepuh silat ataupun perguruan pencak silat yang hidup hanya dalam suatu komunitas di kampung yang spesifik. Hal itu karena mereka dianggap tidak bersinggungan dengan perguruan pencak silat lain sehingga tidak terjadi percampuran atau saling meniru gerakan satu sama lain antar perguruan. Menurut Jemi, anak kandung dan murid Aus, “...kalau mau melihat paguron (perguruan) yang masih asli gerakannya, belum bercampur sama yang lain, itu lihat paguron yang hanya aktif di kampungnya masing-masing. Itu belum ketemu sama paguron lain. Silatnya masih asli".

Kami mendatangi salah satu perguruan pencak silat yang hanya aktif di kampung yaitu perguruan Dharma Bakti yang berlokasi di Darmaraja. Perguruan ini dipimpin oleh Mang Nana. Ia menceritakan bahwa perguruan ini merupakan perguruan silat ibing buhun yang berarti ibing tua. Ibing merupakan seni pertunjukan pencak silat yang diiringi oleh musik yang melantunkan irama tertentu (Paetzold 2016: 83-91). Selain 
menampilkan unsur keindahan gerak, menurut Wilson (2002: 93), ibing menjadi fokus utama pengembangan silat di Jawa Barat pasca kemerdekaan hingga tahun 1960an. Gerakan-gerakan pencak silat dalam ibing dibuat menyerupai gerakan tarian akan tetapi sarat dengan fungsi beladiri. Hal itu berbeda dengan silat tarung yang berfokus pada gerakan-gerakan serangan dan pertahanan diri dan dipelajari bukan untuk tujuan pertunjukan. Nana belajar ibingan dari tiga orang guru yang semuanya adalah pelatih ibing silat Cimande yang dianggap sebagai salah satu aliran silat buhun di Sumedang. Menurutnya, ketiga orang pelatih tersebut memiliki gerakan ibing yang bagus. Ia mengombinasikan gerakan ibing yang ia pelajari dan menjadikannya sebagai versinya sendiri. Nana menambahkan bahwa paguron yang ia dirikan berfokus pada pengajaran ibing saja dan bukan pada silat tarung. Hal itu ia tegaskan dengan penolakan untuk bergabung dengan IPSI sejak tahun 1983. Perguruannya pernah ditawarkan untuk bergabung dengan IPSI tetapi Nana tolak karena paguron miliknya adalah paguron khusus silat ibing.

Garuda Putih memiliki beberapa gerak khas dari perguruan mereka yaitu gerakan yang menyerupai cakar seekor burung garuda. Teknik-teknik atau jurus mereka halus dalam arti mengandalkan gerak dan tenaga lawan sebagai sumber kekuatan untuk menjatuhkan dan melumpuhkan lawannya. Dalam bahasa Handi, seorang pelatih di Garuda Putih, "...kalau silat sunda tuh leleus liat lentur tapi alot" (Silat Sunda itu lemas, liat, lentur tapi bertenaga). Selain halus, Garuda Putih mengandalkan rasa (penghayatan) dalam setiap gerak jurusnya untuk dapat menghasilkan pergerakan yang indah dalam setiap gerak jurus maupun rangkaian ibing-nya. Penekanan pada rasa inilah yang membuat gerakan jurus dalam Garuda Putih walaupun tampak halus namun memiliki daya serang yang mampu menjatuhkan dan melumpukan lawan.

Sebagai sebuah paguron pencak silat, Garuda Putih memiliki indikator untuk menilai penguasaan silaat muridnya. Setiap murid yang ingin naik tingkat ke tingkat pelatih, dengan sabuk merah, harus melalui suatu persyaratan yaitu mampu menciptakan rangkaian gerak ibing versinya sendiri. Persyaratan ini menjadi sesuatu yang mutlak harus dipenuhi oleh setiap calon pelatih, selain sikap bertanggung jawab seorang murid kepada perguruan dan dirinya sendiri. Dua pertanyaan yang muncul selanjutnya adalah bagaimana implikasi persyaratan kenaikan tingkat ini terhadap otentisitas gerak dan jurus dalam Garuda Putih dan bagaimana Garuda Putih memandang proses kreatif di dalam dirinya terhadap rangkaian gerak ibing terhadap persoalan pewarisan gerak jurus khas Garuda Putih.

\section{- Perkembangan pengajaran silat di Garuda Putih}

Aktivitas perguruan Garuda Putih sempat tidak berjalan sementara sejak tahun 1990an hingga tahun 2008 karena Abah Aus tidak memiliki banyak murid selama kurun waktu tersebut. Paling banyak murid yang dilatih oleh Abah Aus selama tahun-tahun tersebut adalah lima orang. Pada masa ini banyak perguruan bela diri dari luar wilayah Indonesia seperti karate, taekwondo, muay thai dan lain sebagainya berkembang pesat dan menarik minat generasi muda. Menurut para pelatih di Garuda Putih, pada masa-masa inilah pencak silat kehilangan peminatnya. Handi mengungkapkan pandangan itu dengan mengatakan bahwa "anak-anak sekarang mah lebih tertarik sama bela diri luar. Padahal kita punya bela diri yang banyak dan bagus di sini". Pandangan 
bahwa pencak silat adalah bela diri yang tradisional dan ketinggalan zaman menyebabkan generasi muda melihat pencak silat sebagai aliran bela diri yang tidak lagi menarik di tengah masyarakat modern. Gejala ini diamati oleh forum pelatih muda Garuda Putih yang disebut Simpay Wulung Tengkorak Putih, yang selanjutnya kami singkat simpay wulung, sehingga mereka memutuskan untuk melakukan perubahan sistem dan pola latihan yang ada di Garuda Putih.

Garuda Putih bergabung dengan IPSI sejak tahun 1990 dan aktif mengikuti berbagai kegiatan IPSI mulai tahun 2010. Alasan bergabungnya Garuda Putih dengan IPSI adalah karena kebutuhan untuk mempertahankan eksistensi perguruan. Sebelumnya, Garuda Putih tergabung dalam Persatuan Pencak Silat Indonesia (PPSI) yang berfokus pada pencak silat di Jawa Barat dan kesenian ibing. IPSI dan PPSI adalah asosiasi silat yang sempat sama-sama memiliki anggota banyak dan terlibat dalam persaingan organisasi, antara lain karena IPSI dianggap terlalu berkiblat pada aliran silat Jawa (Mataraman), sementara PPSI lebih berorientasi ke silat Jawa Barat (de Grave 2016: 55; Paetzold 2016: 112). Pada beberapa tahun terakhir, PPSI dianggap jarang mengadakan ajang kompetisi maupun pertunjukan yang menampilkan perguruan-perguruan pencak silat anggotanya. Hal ini dianggap menghambat perguruan pencak silat yang tergabung di dalamnya untuk menunjukkan eksistensi mereka dihadapan perguruan lain maupun generasi muda yang akan menjadi penerus perguruan mereka. Berbeda halnya dengan IPSI dan perguruan-perguruan pencak silat anggotanya yang secara rutin melakukan ajang kompetisi pertandingan tarung di berbagai wilayah termasuk di Sumedang. Dengan demikian, para pelatih muda yang merupakan anak buah dari Abah Aus, memutuskan untuk mengikutsertakan Garuda Putih ke dalam IPSI dan aktif mengikuti berbagai kegiatan yang diadakan oleh IPSI dan perguruan anggotanya. Adit, seorang pelatih di Garuda Putih, menjelaskan,

"Jadi Garuda Putih itu pembaruan dari Tengkorak Putih. Abah juga kan sempat vakum mengajar karena selain ngga ada murid, pola latihannya juga kurang menarik minat pemuda. 2009 kita mulai coba sistem baru. Kita ngikut ke IPSI dan coba pakai pola latihan baru juga"

Sejak tahun 2009, simpay wulung mulai mengikuti secara aktif berbagai kegiatan IPSI. Pada tahun itu pula Garuda Putih secara resmi mendapatkan Surat Keputusan dari pengurus IPSI. Bersamaan dengan hal tersebut terjadi perubahan pola pelatihan di dalam Garuda Putih yang dilakukan oleh forum simpay wulung. Pertama kali, setiap murid diajari rangkaian gerak ibing terlebih dahulu, dimulai dengan rangkaian ibing palered lima sebagai dasar rangkaian. Palered atau paleredan, berasal dari kata Plered sebuah nama kecamatan di wilayah Purwakarta yang menjadi asal aliran silat Cimande (Setiawan 2011:409), adalah variasi irama yang dihasilkan musik perkusi yang mengiringi latihan silat, terutama kendang dan gong (Paetzold 2016:82-83, 245). Ibing palered lima ini gerakannya berbeda pada masing-masing perguruan silat. Setelah murid menguasai seluruh rangkaian ibing dasar mulai dari palered lima, tepak dua dan tepak tilu, murid mulai mempelajari gerak jurus. Tepak merujuk pada rumus pukulan kendang (Paetzold 2016:82); kecepatan ritme dan kekerasan bunyinya berpengaruh terdapat kecepatan gerak pesilat. Gerak jurus dalam Garuda Putih baru akan diajarkan 
pada saat seorang murid mencapai tingkat pelatih dan menguasai rangkaian ibing dasar.

Pemahaman dan penguasaan rangkaian ibing adalah dasar menjadi pesilat Garuda Putih, tetapi untuk belajar gerak jurus mereka harus memiliki kesiapan mental, mampu mengendalikan emosi dan memiliki kedewasaan sikap. Pola latihan yang demikian dianggap membosankan karena proses menguasai rangkaian ibing membutuhkan waktu yang relatif lama; bisa dua-tiga tahun tergantung kemampuan belajar dari masing-masing murid. Itulah mengapa banyak calon murid yang lebih memilih untuk belajar bela diri di perguruan lain atau bahkan ke perguruan bela diri dari luar Indonesia. Melihat fenomena ini, para simpay wulung mengubah sistem tingkatan berdasarkan sabuk, sesuai dengan penguasaan ibing dan jurus awal. Adit yang merupakan seorang anggota simpay wulung generasi sebelum tahun 2009 dan membuat perubahan pola latihan bercerita,

\begin{abstract}
“Sabuk pertama kita tuh yang diolah itu musti menguasai ibing palered lima. Itu untuk yang sabuk kuning. Gerakan yang dikuasai hanya gerakan pukulan tangkisan, dan tendangan biasa serta kuda-kuda. Nah itu dasarnya yang diolah. Nah selanjutnya itu sabuk hijau, materi ibingnya sudah harus bisa tepak tilu, menguasai materi tanding IPSI, terus peningkatan pernapasan dan fisik. Ada olah napas juga kan jadi kekuatan fisiknya itu mulai dipakai pas sabuk hijau. Setelah itu kita masuk ke sabuk merah. Kita harus menguasai beberapa ibing yang diajarkan dan bikin sendiri ibing dan jurus sendiri terus diperkenalkan dengan ulin pakarang (bermain senjata) yaitu golok. Nah biasanya cuma tiga tingkatan itu, kuning, hijau sama merah. Nah nanti di tingkatan akhirnya baru kita ada namanya Simpay Wulung itu sabuk hitam. Tidak semua orang bisa sampai ke sabuk hitam. Syaratnya itu benar-benar loyalitas di perguruannya dipertanyakan.
\end{abstract}

Pada setiap tingkatan akan diajarkan materi yang berbeda sesuai dengan apa yang sudah diatur di dalam kurikulum. Sejak diperkenalkan setelah tahun 2010, terdapat delapan tingkat sabuk dalam Garuda Putih, dimulai dari sabuk kuning, sabuk kuning strip hijau, sabuk hijau, sabuk hijau strip merah, sabuk merah, sabuk merah strip hitam, sabuk hitam dan terakhir sabuk putih. Tabel berikut menunjukkan tingkatan dan cakupan materi yang mesti dikuasai murid-murid di Garuda Putih.

Tabel 1. Tingkat kemahiran pesilat Garuda Putih

\begin{tabular}{cll}
\hline Tingkat & \multicolumn{1}{c}{ Nama sabuk } & \multicolumn{1}{c}{ Keterangan } \\
\hline 1 & Sabuk kuning & $\begin{array}{l}\text { Menguasai ibing palered lima; kuda-kuda, } \\
\text { gerakan pukulan tangkisan, tendangan biasa }\end{array}$ \\
\hline 2 & Sabuk kuning strip hijau & $\begin{array}{l}\text { Menguasai tepak tilu, teknik pernapasan awal } \\
\text { dan fisik, memahami materi tanding }\end{array}$ \\
\hline 3 & Sabuk hijau & $\begin{array}{l}\text { Menguasai beberapa ibing standar, menciptakan } \\
\text { ibing dan jurus sendiri, mulai ulin pakarang, } \\
\text { masuk fase meresapi setiap jurus atau wirasa, } \\
\text { boleh melatih murid baru }\end{array}$ \\
\hline 5 & Sabuk hijau strip merah & Sabuk merah \\
\hline 6 & Sabuk merah strip hitam & $\begin{array}{l}\text { Menguasai semua materi, teruji, dan loyal pada } \\
\text { perguruan }\end{array}$ \\
\hline 7 & $\begin{array}{l}\text { Sabuk hitam (simpay } \\
\text { wulung) }\end{array}$ & Guru besar atau pemilik perguruan \\
\hline 8 & Sabuk putih &
\end{tabular}


Sistem tingkatan, dengan wujud sabuk yang dikenakan, dianggap dapat memotivasi setiap murid untuk terus aktif berlatih di perguruan. Dengan naik tingkat, setiap murid akan mendapatkan materi gerak jurus maupun rangkaian ibing yang lebih tinggi. Hal itu berlanjut hingga tingkatan ke tiga yaitu sabuk merah dimana mereka akan menjadi pelatih dengan syarat mampu menciptakan kreasi rangkaian ibing versi mereka sendiri. Pada tingkat ini mulai diajarkan filosofi dari setiap gerak jurus yang telah diajarkan dan akan mendapatkan materi tambahan berupa olah pernapasan. Di tingkat terakhir yaitu sabuk hitam, seorang pelatih dapat bergabung dengan keanggotaan simpay wulung pada saat malam peringatan ulang tahun perguruan. Pada saat itu seorang pelatih yang mengajukan diri untuk naik tingkat ke sabuk hitam akan dinilai kesetiaannya terhadap perguruan melalui hasil pengujian kemampuan ibing, gerak jurus, kemampuan bertarung menghadapi beberapa orang sekaligus, tes ketahanan fisik, dan kemampuan untuk menciptakan jurus dan gerakan baru.

Seorang pelatih pemula akan diamati aktivitas kesehariannya secara diam-diam oleh para anggota simpay wulung selama satu tahun penuh. Pengamatan aktivitas keseharian ini menjadi dasar penilaian tanggung jawab dan kesetiaan seseorang terhadap perguruan. Seorang pelatih, perlu waktu lama untuk menjadi simpay wulung; Teguh, misalnya, menjadi anggota simpay wulung setelah tujuh tahun aktif berlatih dan melatih di Garuda Putih. Saat ini anggota simpay wulung yang aktif sehari-hari di perguruan adalah Aditia, Teguh, Handi, Anyat Hidayat, M. Gofur, dan dua anak Abah Aus yaitu Jemi dan Urip. Hanya lima orang yang aktif melatih karena Anyat dan Urip bekerja di luar Sumedang.

Posisi simpay wulung ini cukup signifikan di dalam Garuda Putih karena Abah Aus mulai mempercayakan setiap urusan pengelolaan perguruan kepada para muridnya yang kini menjadi pelatih muda. Urusan pengelolaan perguruan ini terutama ia serahkan kepada para anggota simpay wulung. Forum ini juga yang mengubah orientasi pengembangan perguruan dari berfokus pada pelatihan ibing menjadi berorientasi prestasi dalam kejuaraan pencak silat. Teguh menjelaskan perubahan orientasi itu,
“....kalau Garuda Putih itu dulunya fokus ke ngibing. Baru ke pertandingan prestasi itu tahun 2010. Kalau ingin lebih jelasnya itu ke kang Jemi atau kang Adit yang menjadi pelatih ketika masa itu. Jarang sih sekarang perguruan silat yang masih aktif ibingnya, sekarang lebih ke tanding soalnya ibing kan PPSI. Sekarang PPSInya saja sudah ngga aktif. Pengurusnya kurang aktif. Setahun juga jarang ngadain event kayak ibing gitu. Kalau IPSI sih tarung gelanggang kan banyak tiap tahun ada.

Saat ini para pelatih dan anggota Garuda Putih mulai memfokuskan diri pada upaya untuk meraih gelar juara dalam berbagai pertandingan pencak silat. Salah satu tujuan mengikuti pertandingan adalah untuk menunjukkan eksistensi perguruan di wilayah Sumedang sekaligus mengenalkan Garuda Putih kepada generasi muda. Saat penelitian berlangsung, bulan Oktober tahun 2019, Garuda Putih mengikuti kejuaraan pencak silat di Universitas Sebelas April di Sumedang dan memenangi empat gelar juara dari lima orang yang didelegasikan. Keberhasilan Garuda Putih dalam berbagai kejuaraan tersebut membuat nama paguron Garuda Putih Setia Kawan semakin dikenal oleh para pengurus perguruan pencak silat lain di Sumedang. Di samping itu, saat ini 
pun Garuda Putih mulai membuka cabang di beberapa sekolah di Kabupaten Sumedang dan mengutus para pelatih muda yang masih aktif bersekolah di tingkat sekolah menengah pertama (SMP) dan sekolah menegah atas (SMA) sebagai pelatih di sekolah-sekolah yang menjadi cabang perguruan.

\section{- Ujian menciptakan ibing sendiri}

Di dalam kurikulum pelatihan Garuda Putih, terdapat beberapa jenis rangkaian ibing mulai dari palered yang terdiri dari palered lima, palered enam, palered tujuh, palered depan dan palered sembilan. Kemudian ada tepak dua dan tepak tilu. Tepak, yaitu iringan musik silat, biasanya terdiri dari lima putaran ritma; kendang indung (kendang besar) ditabuh sebagai patokan bunyi, lalu kendang anak berimprovisasi mengisi irama. Selanjutnya tarompet menimpali dengan melodi yang sesuai (Spiller 2016:324). Semakin tinggi hitungan tepak, semakin cepat tempo gerakan pemain silat. Tepak dua adalah yang temponya paling lambat, meningkat semakin cepat ketika tepak tilu. Semakin banyak jumlah gerakan dalam palered, semakin banyak dan cepat ketukannya seperti pada palered enam yang lebih banyak gerakannya dibandingkan palered lima dan seterusnya. Perbedaan yang dimiliki oleh setiap rangkaian ibing adalah jumlah gerakan dalam setiap bukaan (rangkaian gerak) dalam satu kali penampilan dan juga jumlah ketukan kendang atau alat musik lainnya yang dimainkan.

Rangkaian ibing palered lima adalah rangkaian ibing dasar yang pasti sama diajarkan kepada setiap murid. Rangkaian ibing palered enam, tujuh, delapan dan sembilan serta tepak dua dan tepak tilu adalah hasil kreasi setiap pelatih. Menciptakan rangkaian baru ibing menjadi suatu yang penting dalam Garuda Putih, karena menurut Jemi menunjukkan kematangan seorang pesilat dalam menggali sendiri ilmunya.

"kalau beladiri kan itu pengembangan diri ya, kalau dia nunggu disuapin pelatih tuh nanti biasanya dia tidak berkembang. Kalau saya kan sebagai pelatih ya A, tugasnya di sini kan cuman ngasih dasar. Nah ini dasarnya ini gerakannya, kamu mau buat apa nantinya?"

Kewajiban untuk menciptakan rangkaian ibing diterapkan agar Garuda Putih dapat terus melakukan modifikasi gerak jurus yang dimiliki perguruan. Setiap pelatih dituntut untuk memiliki kemampuan mengembangkan kemampuan diri masingmasing melalui penciptaan kreasi ibing. Hal itu dilakukan agar Garuda Putih dapat mengikuti perkembangan kesenian ibing yang ada di Sumedang maupun Jawa Barat secara keseluruhan dan juga menarik minat generasi muda sebagai penerus perguruan. Jemi menambahkan dengan, "kita perlu modifikasi, supaya bisa ngikutin perkembangan zaman juga. Kalau ngga ada perubahan kan anak-anak sekarang tuh melihatnya jadi monoton, mereka malas ikut latihan nantinya". Kreasi ibing diciptakan melalui perpaduan gerakan beberapa palered, palered dengan tepak dua atau tepak tiga dan berbagai gerak yang belum ada di Garuda Putih.

Garuda Putih terus diperkenalkan pada masyarakat luas. Selain mengikuti berbagai kejuaraan yang diadakan di wilayah Sumedang, perguruan dan para pesilat aktif mempertontonkan ketrampilannya pada berbagai kegiatan seperti parade, festival bahkan perayaan pernikahan. Upaya ini diawali ketika Jemi, anak dari Abah Aus, yang saat menikah meminta para anggota Garuda Putih melakukan pertunjukan 
kreasi gerak jurus dan ibing dalam pesta pernikahannya. Sejak saat itu Garuda Putih mendapatkan beberapa tawaran pertunjukan pada beberapa pesta pernikahan warga sekitar perguruan hingga ke Jakarta. Aktifnya Garuda Putih dalam berbagai kegiatan sebagai penampil pertunjukan kesenian membuat nama perguruan semakin dikenal oleh masyarakat Sumedang. Pada setiap penampilan seni ibing (ngibing) di berbagai agenda tersebut para penampil memperlihatkan rangkaian ibing hasil kreasi mereka sendiri ataupun hasil kreasi pelatihnya yang telah diajarkan kepada mereka.

Meskipun kreasi rangkaian ibing secara umum merupakan hasil kombinasi gerakan dalam palered lima, tepak dua, tepak tilu dan berbagai gerak jurus lainnya dari Garuda Putih, ada juga pelatih yang memadukan gerak ibing dari perguruan lain ke dalam rangkaian ibing yang ia ciptakan. Teguh, seorang pelatih yang telah membuat lebih dari tujuh rangkaian ibing mengatakan

"Iya, nah nanti kan saya lihat, oh ya gerakannya begitu. Nanti saya campurin. Ngga akan tau dia kalau saya ngambilnya ngga full. Kalau saya pelajarin dan saya ikutin full ibingnya itu baru dia akan komen (protes). Kalau misalnya satu bukaan saya ambil satu dua gerakan, ngga akan tau dia juga. Hampir sama atuh kayak selut, sikutan. Cuman kan dia kebanyakan gayanya beda, ada yang sambil nariknya gayanya begini (memeragakan) ada juga yang gini (memeragakan). Nah itu kan beda-beda gayanya. Paling itu aja."

Anggapan bahwa gerakan pencak silat relatif sama pada setiap perguruan hanya berbeda nama dan sikap atau posisi langkah dan kuda-kuda, yang antara lain disebabkan oleh kemungkinan asal usul dan pengaruh yang sama (Facal 2016:165), membuat tindakan mengombinasikan gerakan dari perguruan lain ke dalam rangkaian ibing Garuda Putih menjadi sesuatu yang dianggap wajar. Hanya saja terdapat suatu aturan tegas bahwa setiap gerakan yang ditambahkan ke dalam suatu rangkaian ibing harus mengikuti ciri khas perguruan dalam sikap tubuh untuk setiap gerak jurus dan tidak diperbolehkan menggunakan gerak jurus khas perguruan lain. Selain itu, setiap perguruan tidak dapat mengklaim bahwa suatu gerak jurus adalah otentik miliknya karena alasan percampuran ragam gerak jurus dari berbagai perguruan. Setiap perguruan hanya mampu mengklaim rangkaian gerak ibing sebagai hasil kreasi mereka dan oleh karenanya menjadi khas milik perguruan masing-masing.

Meskipun perpaduan gerak jurus dari berbagai perguruan ke dalam gerak jurus suatu perguruan, terdapat beragam sikap yang berbeda pada setiap perguruan terkait kesediaan mereka dalam berbagai gerak jurus maupun rangkaian ibing kepada perguruan lain. Teguh menceritakan pengalamannya ketika mencoba untuk mempelajari rangkaian ibing dari perguruan lain dengan mendatangi beberapa perguruan pencak silat di Sumedang. Menurutnya ada perguruan yang membuka diri mereka untuk berbagai ilmu dan gerak jurus kepada anggota perguruan lain dan ada juga yang menutup diri. Perguruan yang menutup diri mereka berupaya untuk menjaga agar rangkaian ibing mereka sebisa mungkin tidak dipelajari oleh anggota perguruan lain. Perguruan yang membuka diri untuk berbagi ilmu rangkaian ibing kepada perguruan lain biasanya adalah perguruan yang juga aktif terlibat di IPSI. Perguruan-perguruan yang aktif berkegiatan dalam berbagai agenda IPSI cenderung lebih membuka diri karena mereka pun saling mempelajari gerak jurus dan teknikteknik dari perguruan lain melalui pengamatan masing-masing. 


\section{- Proses kreasi identitas pelatih dan perguruan}

Para pelatih di Garuda Putih dituntut menunjukkan karakter inovatif dalam mengupayakan keberlanjutan perguruan. Penerapan kewajiban menciptakan rangkaian ibing versi masing-masing calon pelatih sebagai syarat menjadi pelatih adalah upaya untuk terus-menerus melakukan kreasi dan revisi internal di dalam Garuda Putih. Hal itu dilakukan untuk menciptakan otentisitas perguruan sebagai komunitas dan masing-masing pelatih secara individual. Garuda Putih berhadapan dengan perguruan lainnya yang juga merupakan perguruan dengan karakteristik relatif sama yaitu hasil perpaduan beberapa aliran pencak silat. Setiap perguruan berupaya untuk menunjukkan otentisitas mereka melalui penciptaan rangkaian ibing khas masing-masing perguruan dengan penciptaan pakem-pakem tertentu dalam rangkaian ibing kreasi masing-masing perguruan. Jemi dan Abah Aus menegaskan hal tersebut,

\footnotetext{
"kita tidak bisa klaim suatu jurus itu milik kita karena setiap paguron itu relatif sama gerak jurusnya. Tapi kita bisa klaim rangkaian ibing itu asli punya kita karena urutan gerak jurus dan kreasinya itu tidak mungkin sama persis". (Jemi)

"Ya kan semua paguron juga digabung-gabung gerakannya. Ngga bikin sendiri ngga, gabungan itu, cuma setiap padepokan punya khasnya masingmasing itu. Kalau Garuda Putih tuh ciri khasnya ya pasangan-pasangan (sikap pasang dan kuda-kuda), cakar-cakar itu ya ciri khasnya". (Abah Aus)
}

Setiap perguruan memiliki rangkaian gerak ibing versinya masing-masing yang memiliki kemiripan tetapi berbeda urutan dan komposisi gerak dalam setiap bukaan. Gerakan yang relatif sama ditemukan pada jurus khas setiap perguruan di Sumedang dan di berbagai wilayah lainnya. Hal ini disebabkan oleh riwayat perpaduan dari berbagai gerak jurus dari bermacam-macam aliran pencak silat. Perbedaan yang ada hanya berupa sikap tubuh dan posisi kuda-kuda ketika melakukan gerak jurus tertentu. Selain itu, faktor yang membedakan suatu perguruan dengan perguruan lainnya adalah penamaan gerak jurus. Contohnya adalah gerak selut yaitu gerakan menarik tubuh lawan-biasanya tangan atau kaki-lalu mematahkan bagian yang ditarik menggunakan pangkal telapak tnagan yang berbeda penyebutannya pada beberapa perguruan. Garuda Putih menyebutnya dengan selut sedangkan di perguruan lain ada yang menyebutnya dengan selup atau selur.

Kasus di atas kami lihat sebagai upaya dari Garuda Putih sebagai lembaga untuk meneguhkan ciri otentik perguruannya. Sebuah upaya agar perbedaan yang menjadi keunggulan mereka dapat terlihat pihak lain. Di sisi individual, para pelatih melakukan disposisi, suatu perilaku yang menjadi strategi menghadapi standarisasi yang digariskan perguruan. Ketika murid sampai sabuk merah, mereka diminta untuk keluar dari garis standar perguruan, menciptakan gerak ibing dan jurus yang berbeda. Ini adalah persoalan bagaimana struktur, yaitu lembaga perguruan, memberikan peluang bagi individu, yaitu murid sabuk merah, untuk melakukan improvisasi. Referensi pengembangan jurusnya nampaknya lebih praktikal; tidak melalui penciptaan dengan mengamati fenomena alam, tetapi juga melihat dan mengkombinasikan jurus dari perguruan lain. 
Peniruan gerak jurus dari perguruan lain dan mengadaptasikannya menjadi gerak jurus perguruan sendiri dilakukan bukan secara sembarang. Adit mengatakan bahwa ketika ia mempelajari setiap gerak jurus ia akan berupaya merenungi dan melihat fungsi gerak jurus tersebut dalam imajinasinya mengenai pertarungan di kehidupan keseharian. Ia mengatakannya sebagai berikut, "Kan kita lihat juga kang itu gerakannya fungsinya gimana kalau kita terpaksa berkelahi beneran". Ketika mengadopsi gerak jurus perguruan lain pun, para pelatih memodifikasinya untuk dapat digunakan secara efektif dan efisien dalam pertarungan. Adit menjelaskan ketika ia mengadopsi suatu gerak jurus ke dalam gerak jurus Garuda Putih sebagai berikut "iya dimodifikasi lah istilahnya itu buat benar-benar dipakai real beladiri asli. Itu dalam jurus". Modifikasi tersebut terutama menyesuaikan pada pola sikap tubuh dan posisi kuda-kuda.

Meskipun silat di Sumedang sudah melalui proses percampuran berbagai aliran pencak silat sejak lama, tetapi memodifikasi gerak jurus pada tahap tertentu menimbulkan sikap kontra dari beberapa pihak. Adit yang memodifikasi sikap tubuh dari beberapa gerak jurus yang ia tiru dari aliran pencak silat tertentu, mendapatkan kritik dari beberapa sesepuh perguruan pencak silat di Sumedang yang masih mempertahankan tradisi ibing buhun pada suatu forum pertemuan antarperguruan. Adit menceritakan bahwa ia mendapatkan pertanyaan, "nanaonan eta diubah?" (apaapaan itu diubah?). Namun menurut Adit, ketika gerak jurus tidak lagi efektif dan hanya sekadar untuk keindahan, maka gerak jurus tersebut perlu dimodifikasi dalam pelatihan gerak jurus tetapi tidak harus dimodifikasi dalam rangkaian gerak ibing. Menurut Adit ibing ditujukan untuk seni pertunjukan sehingga tidak ada masalah untuk tetap mempertahankan keaslian gerak jurusnya.

“....Jurus buhun tuh kelihatannya polos, ngga banyak reka-reka. Paling cuman nangkis biasa doang. Ngga banyak tambahan goyang-goyangannya. Kan sekarang mah sudah campur seni.... Ya biar sama orang keliatannya ngga terlalu ketinggalan seninya, ngga kurang gitu. Tapi silat buhun juga ngga dihilangkan, masih tetap gerakannya ngga hilang gitu. Dikreasiin sama anakanak. Ibingnya juga masih utuh ibing buhunnya. Cuman sama anak-anak dikreasikan. Cuman jurusnya mah ngga akan hilang".

Penciptaan kreasi ibing ini menjadi suatu dasar legitimasi bagi perguruan Garuda Putih untuk mengklaim diri sebagai perguruan yang memiliki karakteristik otentiknya sendiri. Rangkaian gerak ibing yang diciptakan anggota perguruan menjadi milik perguruan yang khas, berbeda dengan rangkaian ibing perguruan lainnya. Garuda Putih menjadi otentik dengan kekhasannya untuk terus menciptakan kreasi rangkaian ibing yang berbeda dengan perguruan lain. Dengan demikian dapat dikatakan Garuda Putih berupaya untuk menjadi yang otentik dengan karakter inventifnya. Selain itu, meskipun dalam hal keragaman gerak jurus Garuda Putih tidak memiliki perbedaan signifikan dengan perguruan lain, tetapi dalam hal asal usul tempat kelahiran perguruan, Abah Aus mengklaim Garuda Putih sebagai perguruan asli Sumedang. Abah Aus pun menganggap bahwa Garuda Putih merupakan perguruan pencak silat yang lahir di Sumedang dan merupakan hasil olah pemikiran dan ilmu bela diri yang dilakukan secara mandiri. Pandangan itu membuat Abah Aus mengatakan bahwa Garuda Putih adalah pencak silat asli atau otentik yang lahir dan berkembang di Sumedang. 


\section{- Menakar otentisitas}

Dalam perspektif antropologi, suatu ciri atau identitas, meskipun rumit secara konseptual (Golubovic 2011), adalah hal yang amat dibutuhkan seseorang dalam lingkup sosialnya. Identitas menjadi bagian dari aktualisasi individu dalam masyarakat yang lebih luas. Keperluan untuk adanya rekognisi membuat individu dan kelompok berupaya menampilkan ciri yang khas dari mereka. Otentisitas menjadi bagian penting karena keaslian itulah yang akan selalu dicari dan diingat, suatu hal yang menurut Urry (2003) selalu dikonsumsi orang lain. Walaupun demikian, para ahli antropologi sudah memperingatkan kemungkinan masalah ketika menggunakan konsep otentisitas, terkait dengan posisi sang ahli maupun kerancuan cara pandang (Linnekin 1991; Theodossopoulos 2013). Kami akan mengkaitkan dilema mengenai otentisitas yang disampaikan Theodossopoulos (2013) dengan kasus pada upaya mengklaim otentisitas silat, jurus, atau ibing yang dikembangkan di Garuda Putih.

Pesoalan pertama, kita cenderung mencari adanya satu sumber yang tunggal dari suatu ide atau realitas sosial. Padahal, sebagaimana silat Sumedang yang asli atau otentik, dapat ditelusur sumbernya dari banyak aliran. Kita akan temukan bahwa silat asli Sumedang bersumber dari aliran Cimande, Cikalong, Syahbandar, dan Madi. Ke dua, jebakan otentisitas ketika mencoba mempertegas kontradiksi antara yang otentik dan yang tidak otentik. Sedikit banyak, hal ini terkait dengan kepentingan kita ketika melihat isu otentisitas (Linnekin 1991). Saat kita mencari jurus asli Garuda Putih, misalnya, kita akan terjebak pada kesimpulan apakah jurus baru yang dibuat itu otentik atau tidak. Kontrakdiksi itu menjebak karena otentik dan tidak otentik memang berada dalam satu garis yang tak putus; kita paham bahwa jurus-jurus baru itu merujuk pada jurus dan gerak ibing dari perguruan lain, artinya terinspirasi dari jurus yang sudah ada sebelumnya. Ke tiga, ironi terkait dengan keaslian suatu tradisi yang sebenarnya merupakan invensi baru. Hal ini biasanya terjadi ketika menjelaskan tradisi di tingkat nasional, seperti mengklaim bahwa silat adalah tradisi Indonesia. Tentu saja harus berhati-hati karena silat Indonesia, seperti yang ditawarkan IPSI, adalah suatu invention of tradition yang berakar dari tradisi lokal (Hobsbawn \& Ranger 2012). Ke empat, apa yang menjadi kriteria dari penentuan sesuatu dianggap itentik atau tidak; ibing, jurus, atau silat seperti apa yang dianggap otentik? Ke lima, otentisitas itu bergerak secara simultan, tidak ada kondisi otentik yang tunggal. Silat, sekali lagi bisa dianggap tradisi nasional atau lokal, tapi pada saat yang sama kita dapat menemukan ciri dari kebudayaan lain.

Untuk menengahi dilema mengenai otentisitas itu, kami mengajak untuk melihat dimensi otentisitas sebagai peristiwa kultural yang simultan dan majemuk (Handler 1986; Hanson 1989; Theodossopoulos 2013:339). Kami melihat hal ini tepat dengan kondisi pada perguruan Garuda Putih. Benar bahwa perguruan tersebut dianggap menawarkan contoh silat Sumedang asli, silat buhun yang otentik; tapi di sisi lain kita melihat pengaruh dari tradisi silat lain. Pun demikian ketika pesilat mereka menciptakan gerak ibing baru yang otentik; persepektif ini menawarkan penilaian atas otentisitas yang majemuk. Sekalipun demikian, para pemerhati silat dan pesilat dari perguruan lain sepakat mengenai identitas Garuda Putih yang memang berbeda dengan perguruan yang lain. 
Demikian pula di tingkat individu. Proses penciptaan gerak ibing baru, yang menandai tingkatan lebih tinggi dari seorang pesilat, dapat dirasakan oleh para simpay wulung dan Abah Aus. Ditambah dengan kasus Adit, ketika ibingnya dikritik sesepuh perguruan lain, menunjukkan bahwa relasi kuasa yang berbeda tetap ada di kalangan murid perguruan bersabuk coklat yang hendak menjadi pelatih, anggota simpay wulung, Abah Aus, dan para sesepuh perguruan silat lain. Mereka bergerak membuat struktur baru yang mengontrol proses kreatif individu sehingga proses tersebut tidak pernah benar-benar menjadi proses individual. Oleh karena itu, walaupun tercipta identitas garuda Putih sebagai satu lembaga, atau penciptaan ibing pada seorang calon pelatih Garuda Putih sehingga dianggap otentik milik sang calon pelatih, kami melihatnya sebagai sebuah otentisitas majemuk sebagai hal yang biasa dalam tradisi Sumedang yang komunal. Hal ini berbeda dengan pandangan individu barat yang tidak melihat otentisitas sebagai proses kultural tetapi sebagai semacam copyrights dari seseorang (Handler 1986:2).

Dalam hal kreasi ibing baru, struktur dasar yang dikembangkan para pimpinan perguruan Garuda Putih adalah penghayatan setiap gerak dan jurus yang digunakan. Abah Aus dan para simpay wulung menilai penghayatan para calon pelatih pada manifestasi wirasa, wiraga dan wirahma, yang merujuk pada kehalusan budi dan gerak, kekuatan, dan ketepatan irama dalam bergerak. Karakteristik ini menjadikan Garuda Putih berbeda dengan perguruan lain seperti Dharma Bhakti yang lebih menekankan pada aspek keindahan saja dan Merpati Putih (Khunaefi 2015) yang menekankan pada faktor wiraga. Dalam perspektif yang kami tawarkan, upaya kreatif untuk menciptakan ibing sendiri, sesuatu yang otentik milik calon pelatih, tetap akan distrukturkan oleh ranah kuasa di luarnya. Demikian pula dengan upaya Garuda Putih untuk membedakan diri dengan perguruan lain. Sekalipun demikian bukan berarti, setelah distrukturkan, semuanya menjadi sama; kita tetap masih bisa melihat ciri otentik dari masing-masing calon pelatih dan perguruan Garuda Putih dibanding dengan perguruan yang lain.

\section{Kesimpulan}

Studi ini menyajikan deskripsi mengenai silat Sumedang dengan mengambil kasus pada perguruan silat Garuda Putih. Secara umum, sebagaimana tradisi pencak silat di Indonesia, silat Sumedang dapat ditelusuri dari berbagai macam aliran. Studi kami menemukan bahwa persoalan modifikasi jurus silat atau rangkaian ibing sebagai bukaan merupakan hal yang amat lumrah sampai sekarang. Sekalipun demikian, pada kasus yang kami angkat, para pesilat dan tokoh-tokoh di Sumedang tetap dapat membedakan secara jelas kekhasan jurus-jurus Garuda Putih.

Di antara kemiripan dan struktur yang sama pada berbagai jurus silat Sumedang, tetap ada kekhasan yang membuat jurus-jurus tertentu menjadi identitas Garuda Putih. Apakah kemudian kita dapat menyatakan jurus itu sebagai otentik milik perguruan tersebut? Melalui makalah ini kami berpendapat bahwa otentisitas itu tetap ada walaupun ada ranah kuasa yang selalu mereproduksi gerak-gerak standar silat dewasa ini. Kami berkesimpulan bahwa otentisitas bukanlah persoalan individu secara eksklusif, tetapi dibentuk melalui proses tarik menarik dengan struktur yang 
berusaha mendisiplinkan individu. Oleh karena itu, otentisitas dalam silat, baik berupa jurus maupun ibing, harus dipandang sebagai otentisitas yang dibentuk simultan dalam rangkaian peristiwa kultural yang menjadikannya bersifat majemuk.

\section{Referensi}

Bourdieu, P. (1977). Outline of a Theory of Practice (Vol. 16). Cambridge University Press.

Bourdieu, P. (1983). The field of cultural production, or the economic world reversed. Poetics, 12(4-5), 311-356.

Bourdieu, P. (1990). The logic of practice. Stanford University Press.

de Grave, J.M. (2016). The Standardisation of Pencak Silat: Javanisation, Nationalism, and Internationalisation. The Fighting Art of Pencak Silat and its Music (pp. 45-75). Leiden, Brill.

Draeger, Donn F. 1972. The weapons and fighting arts of Indonesia. Vermont/Tokyo

Facal, G. (2016). Keyakinan dan kekuatan: Seni bela diri Silat Banten. Yayasan Pustaka Obor Indonesia.

Handler, R. (1986). Authenticity. Anthropology Today, 1(1), 2-4

Hanson, A (1989). The making of the Maori: Culture invention and its logic. American Anthropologist, 91(4), 890-902

Hobsbawm, E., \& Ranger, T. (Eds.). (2012). The invention of tradition. Cambridge University Press.

Kartomi, M. (2011). Traditional and modern forms of pencak silat in Indonesia: the Suku Mamak in Riau. Musicology Australia, 33(1), 47-68.

Khunaefi, M.W. (2015). Pembentukan karakter di Perguruan Pencak Silat Beladiri Tangan Kosong Merpati Putih. Forum Ilmu Sosial (Vol. 42, No. 2, pp. 206-221).

Kriswanto, E.S. (2012). Konsep, proses, dan aplikasi dalam pendidikan kesehatan. Yogyakarta: Fakultas Ilmu Keolahragaan Universitas Negeri Yogyakarta.

Linnekin, J. (1991). Cultural invention and the dilemma of authenticity. American Anthropologist, 93(2), 446-449

Mason, P.H. (2016). Pencak Silat Seni in West Java, Indonesia. The Fighting Art of Pencak Silat and its Music (pp. 235-263). Leiden, Brill.

Nugroho, A.M. (2005). Melatih sikap dan gerak dasar pencak silatbagi pesilat pemula. Jurnal Olahraga Prestasi, 1(2).

Paetzold Uwe U. (2016). The Music in Pencak Silat Arts Tournaments is Gone - A Critical Discussion of the Changes in a Performance Culture. The Fighting Art of Pencak Silat and its Music (pp. 76-124). Leiden, Brill.

Pratama, R.Y. \& Trilaksana, A. (2018). Perkembangan Ikatan Pencak Silat Indonesia (Ipsi) Tahun 1948-1973. Avatara, 6(3).

Rudianto, D. (2011). Mengenal sepintas perguruan seni beladiri Tapak Suci. Golden Terayon Press.

Samudra, J.K. (2006). Body And Belonging: In a Transnatonal Indonesian Silat Community. Proquest Dissertations Publishing, University Of Hawaii, Manoa.

Setiawan, I. (2011). Eksistensi Seni Pencak Silat di Kabupaten Purwakarta (Kajian Tentang Strategi Adaptasi). Patanjala, 3(3), 424-441.

Spiller, H. (2016). Sundanese Penca Silat and Dance Drumming in West Java. The Fighting Art of Pencak Silat and its Music (pp. 317-334). Leiden, Brill.

Urry, J. (2003). The 'consumption' of tourism. The consumption reader, 117-121.

Utomo, D.C. (2017). Pencak Silat Setia Hati Terate di Madiun dari awal sampai pada masa pendudukan Jepang. Avatara, 5(1). 
Willis, P. (1981). Cultural production is different from cultural reproduction is different from social reproduction is different from reproduction. Interchange, 12(2-3), 4867.

Wilson, I.D. (2002). The politics of inner power: The practice of pencak silat in West Java (Doctoral dissertation, Murdoch University). 